\title{
Gambaran Klinis Penyakit Eksantema Akut Pada Anak
}

\author{
Tuty Rahayu, Alan R. Tumbelaka
}

Penyakit eksantema merupakan penyakit yang sering ditemukan pada anak terutama pada awal masa perkembangan seorang anak. Walaupun penyakit eksantema sering memberikan gambaran klinis yang mirip satu dengan yang lainnya, namun sebenarnya setiap penyakit eksantema memiliki karakteristik klinis yang khas sehingga kita harus dapat membedakan satu penyakit eksantema dengan yang lain. Kesalahan diagnosis dapat berdampak kepada pasien, orang yang kontak dengan pasien, dan masyarakat sekitarnya. Diagnosis banding penyakit eksantema ditegakkan berdasarkan pada beberapa faktor, antara lain riwayat penyakit menular dan imunisasi, bentuk gejala prodromal, gambaran erupsi kulit, adanya gejala patognomonik atau tanda lain, dan uji diagnostik laboratoris.

Kata kunci: penyakit eksantema akut - ruam - virus

C enyakit eksantema adalah suatu penyakit yang bermanifestasi sebagai erupsi difus pada kulit yang berhubungan dengan penyakit sistemik yang biasanya disebabkan oleh infeksi. Mekanisme terjadinya lesi kulit adalah kerusakan sel akibat invasi organisme patogen, produksi toksin oleh organisme, dan respons imun pejamu. ${ }^{1,2}$

Pada awal abad ke 20 yaitu pada era pra vaksinasi, klasifikasi penyakit eksantema didasarkan pada urutan kejadian dalam masa perkembangan anak. Campak (measles/rubeola/morbili) disebut sebagai first disease, demam skarlet (scarlet fever) sebagai second disease, rubela (German measles) sebagai third disease, forth disease digambarkan oleh Duke tapi tidak dianggap sebagai golongan tersendiri karena bermanifestasi seperti demam skarlet dan rubela, eritema infeksiosa sebagai fifth disease dan roseola infantum sebagai sixth disease. Klasifikasi ini sekarang tidak digunakan lagi

Dr. Tuty Rahayu: PPDS Ilmu Kesehatan Anak FKUI, Jakarta.

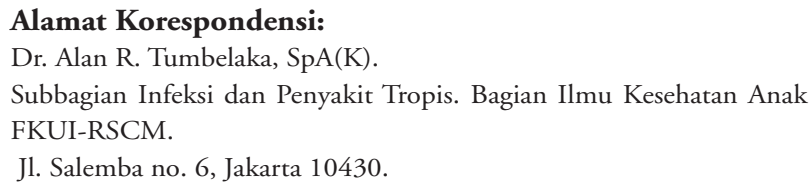

karena telah ditemukan lebih dari 50 organisme (virus, bakteri, riketsia) penyebab penyakit eksantema pada anak. ${ }^{3-5}$

Klasifikasi penyakit eksantema akut pada anak: ${ }^{2}$

1. Gambaran eritema makulopapular.

- Campak

- Campak atipik

- Rubela

- Scarlet fever

- Staphylococcal scalded skin syndrome (SSSS)

- Staphylococcal toxic shock syndrome

- Meningococcemia

- Tifus dan tick fever

- Toksoplasmosis

- Infeksi sitomegalovirus

- Eritema infeksiosum

- Roseola infantum

- Infeksi enterovirus

- Infeksi mononukleosis

- Eritema toksik

- Erupsi obat

- Sunburn

- Miliaria

- Mucocutaneus lymph node syndrome (Penyakit Kawasaki)

2. Gambaran erupsi papulovesikular 
- Infeksi varisela zoster

- Variola

- Eksema herpetikum

- Eksema vaksinatum

- Infeksi virus coxsackie

- Campak atipik

- Rickettsialpox

- Impetigo

- Gigitan serangga

- Urtikaria papular

- Erupsi obat

- Moluskum kontagiosum

- Dermatitis herpetiformis

Penyebab penyakit eksantema sebagian besar adalah virus dan bentuk morfologik yang mirip satu sama lain membuat kita sulit menentukan etiologi berdasarkan klinis. ${ }^{3,5}$ Karena penyakit virus bersifat ringan dan self limited, etiologi spesifik tidak begitu diperlukan. Pada kasus tertentu diagnosis etiologik yang spesifik sangat diperlukan yaitu pada kasus eksantema yang timbul selama masa kehamilan, kasus imunokompromais, dan pada keadaan epidemi. ${ }^{3,6} \mathrm{Di}$ lain pihak pembedaan etiologik antara penyebab bakteri dan riketsia penting dilakukan karena pengobatannya berbeda, terutama yang bersifat fatal. ${ }^{3}$

\section{Campak (measles/rubeola/morbili) ${ }^{1-3,5-7}$}

Etiologi : Morbillivirus (fam. Paramixoviridae)

Masa inkubasi : $14-21$ hari.

Masa penularan : 2 hari sebelum gejala prodromal sampai 4 hari timbulnya erupsi. Cara penularan melalui droplet.

Manifestasi klinis:

- Masa prodromal antara 2-4 hari ditandai dengan demam $38,4-40,6^{\circ} \mathrm{C}$, koriza, batuk, konjungtivitis, bercak Koplik.

- Bercak Koplik timbul 2 hari sebelum dan sesudah erupsi kulit, terletak pada mukosa bukal posterior berhadapan dengan geraham bawah, berupa papul warna putih atau abu-abu kebiruan di atas dasar bergranulasi atau eritematosa.

- Demam sangat tinggi di saat ruam merata dan menurun dengan cepat setelah 2-3 hari timbulnya eksantema.

- Dapat disertai adanya adenopati generali ata dan splenomegali.

- Eksantema timbul pada hari ke 3-4 masa prodromal, memudar setelah 3 hari dan menghilang setelah 6-7 hari.

- Erupsi dimulai dari belakang telinga dan perbatasan rambut kepala kemudian menyebar secara sentrifugal sampai ke seluruh badan pada hari ke3 eksantema.

- Eksantema berupa papul eritematosa berbatas jelas dan kemudian berkonfluensi menjadi bercak yang lebih besar, tidak gatal dan kadang disertai purpura.

- Bercak menghilang disertai dengan hiper-

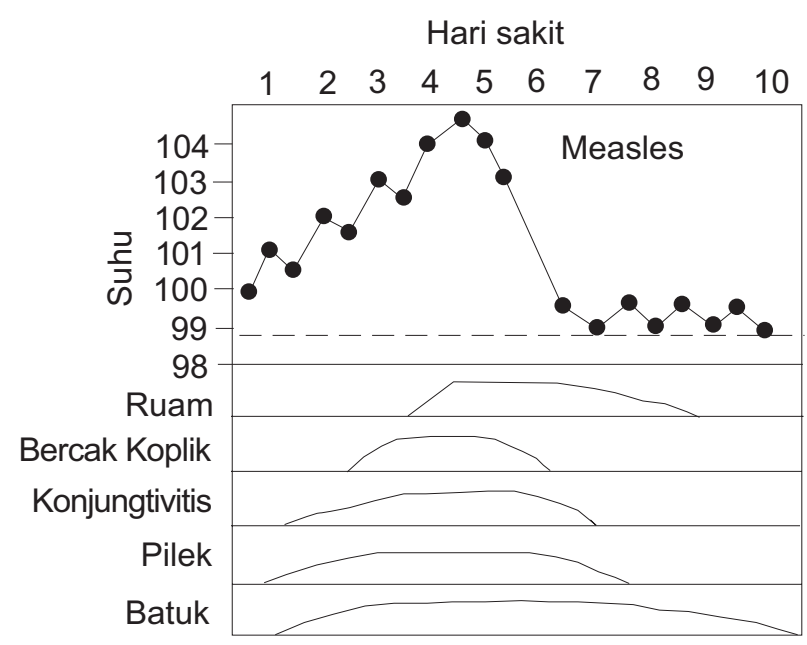

pigmentasi kecoklatan dan deskuamasi ringan yang menghilang setelah 7-10 hari.

- Black measles merupakan keadaan yang berat dari campak, terdapat demam dan delirium diikuti penekanan fungsi pernafasan dan erupsi hemoragik yang luas.

Diagnosis:

- manifestasi klinis, tanda patognomonik bercak Koplik

- $\quad$ isolasi virus dari darah, urin, atau sekret nasofaring

- pemeriksaan serologis: titer antibodi 2 minggu setelah timbulnya penyakit

Komplikasi:

Otitis media, mastoiditis, pneumonia, ensefalomielitis, subacute sclerosing panenchephalitis (SSPE).

Terapi:

Suportif, pemberian vitamin A 2 x 200.000 IU dengan interval 24 jam. 


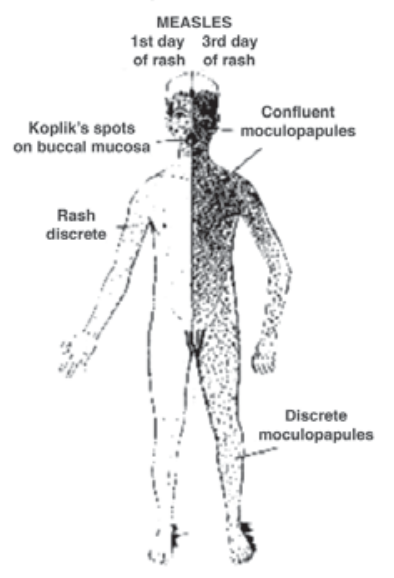

Pencegahan:

Vaksinasi bersama rubela dan mumps (MMR) pada usia 15 - 18 bulan dan ulangan pada usia 10-12 tahun atau 12-18 tahun.

\section{Campak Atipik ${ }^{3,4,6}$}

Etiologi : imunisasi oleh vaksin virus campak yang telah dimatikan.

Patogenesis : delayed hypersensitivity terhadap an tigen virus.

Manifestasi klinis:

- Demam tinggi, nyeri kepala, nyeri otot dan nyeri perut yang disertai pneu monitis. Erupsi kulit tidak seperti campak yaitu berupa urtikaria, makulopapular, ptekie, purpurik dan kadang vesikular dengan predileksi pada ekstremitas. Dapat terjadi edema pada lengan dan kaki serta hiperestesi pada kulit. Bentuk dan distribusi dari eksantema menyerupai rocky mountain - spotted fever.

Terapi: Simtomatik.

Pencegahan: Imunisasi oleh vaksin virus campak hidup yang dilemahkan.

\section{Rubela (German Measles). ${ }^{1-3,6,8-10}$}
Etiologi : Rubivirus (fam. Togaviridae), virus RNA.

Masa inkubasi : $14-21$ hari
Masa penularan:

Sejak akhir masa inkubasi sampai 5 hari setelah timbulnya ruam. Cara penularan melalui droplet.

Manifestasi klinis :

- Masa prodromal 1-5 hari ditandai dengan demam subfebris, malaise, anoreksia, konjungtivitis ringan, koriza, nyeri tenggorokan, batuk dan limf denopati. Gejala cepat menurun setelah hari pertama timbulnya ruam.

- Demam berkisar $38^{\circ} \mathrm{C}-38,7^{\circ} \mathrm{C}$. Biasanya timbul dan menghilang bersamaan dengan ruam kulit.

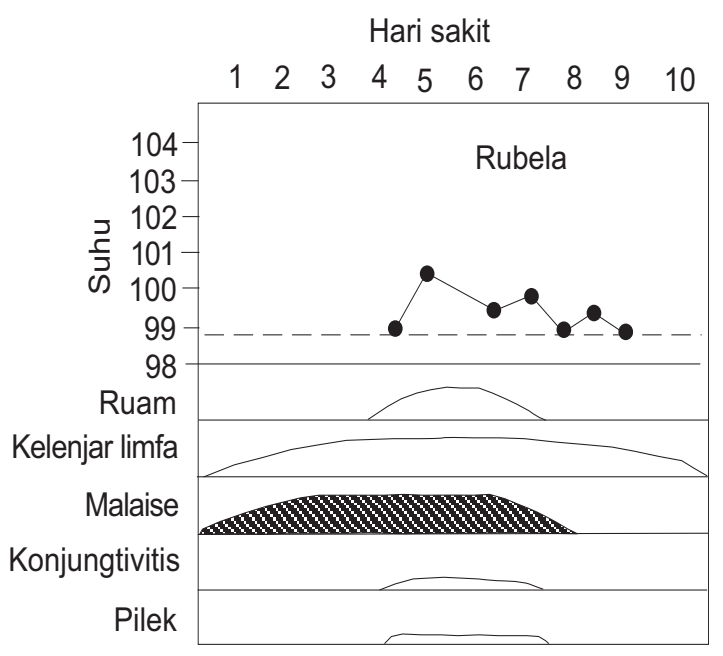

- Enantema pada rubela (Forschheimer spots) ditemukan pada periode prodrodromal sampai satu hari setelah timbulnya ruam, berupa bercak pinpoint atau lebih besar, warna merah muda, tampak pada palatum mole sampai uvula. Bercak Forsch heimer bukan tanda patognomonik.

- Terdapat limfadenopati generalisata tapi lebih sering pada nodus limfatikus suboksipital, retroaurikular atau suboksipital.

- Eksantema berupa makulopapular, eritematosa, diskret. Pertama kali ruam tampak di muka dan menyebar ke bawah dengan cepat (leher,badan, dan ekstremitas) Ruam pada akhir hari pertama mulai merata di badan kemudian pada hari ke dua ruam di muka mulai menghilang, dan pada hari ke tiga ruam tampak lebih jelas di ekstremitas sedangkan di tempat lain mulai menghilang.

Diagnosis:

- Manifestasi klinis yaitu prodromal ringan, ruam 
menghilang dalam 3 hari, limfadenopati retroaurikular dan suboksipital.

- Isolasi virus, virus ditemukan pada faring 7 hari sebelum dan 14 hari sesudah timbulnya ruam.

- Serologis dapat dideteksi mulai hari ke tiga timbulnya ruam.

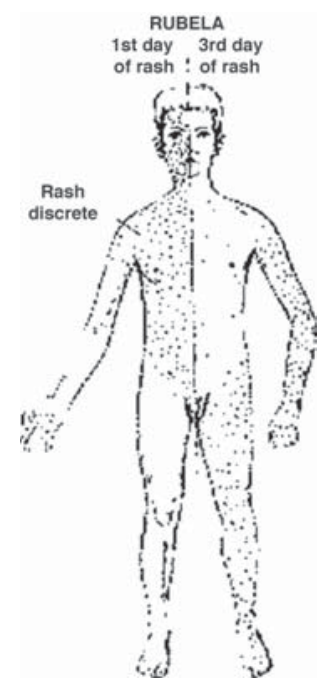

Komplikasi:

Jarang pada anak. Komplikasi dapat berupa artritis, purpura danensefalitis.

Terapi: simptomatik

Pencegahan: vaksinasi MMR

\section{Scarlet Fever (Scarlatina) $)^{1,2-4,6}$}

Etiologi : Streptococcus beta hemolyticus grup A

Masa inkubasi : $1-7$ hari, rata-rata 3 hari

Cara penularan: Melalui droplets dari pasien yang ter infeksi atau karier.

Fokus infeksi : Faring dan tonsil, jarang pada luka operasi atau lesi kulit.

Manifestasi klinis :

- Gejala prodromal berupa demam panas, nyeri tenggorokan, muntah, nyeri kepala, malaise dan menggigil. Dalam $12-24$ jam timbul ruam yang khas.

- Tonsil membesar dan eritem, pada palatum dan uvula terdapat eksudat putih keabu-abuan.
- Pada lidah didapatkan eritema dan edema sehingga memberikan gambaran strawberry tongue (tanda patognomonik).

- Ruam berupa erupsi punctiform, berwarna merah yang menjadi pucat bila ditekan. Timbul pertama kali di leher, dada dan daerah fleksor dan menyebar ke seluruh badan dalam 24 jam. Erupsi tampak jelas dan menonjol di daerah leher, aksila, inguinal dan lipatan poplitea.

- Pada dahi dan pipi tampak merah dan halus, tapi didaerah sekitar mulut sangat pucat (circumoral pallor).

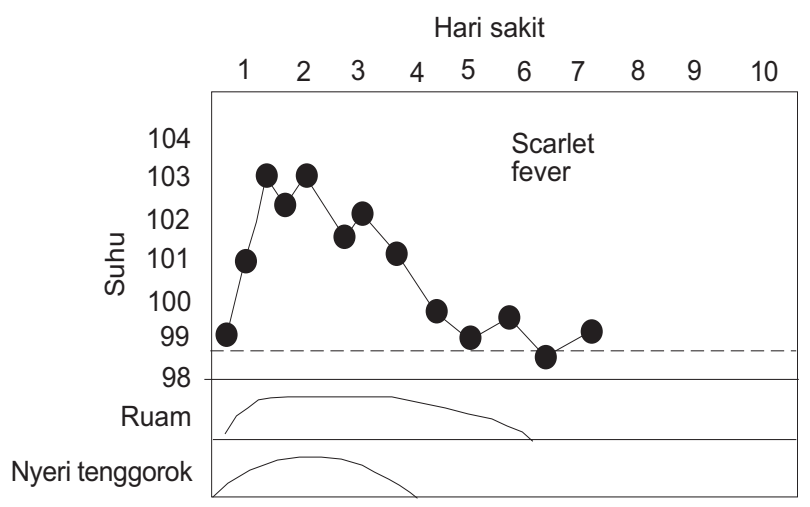

- Beberapa hari kemudian kemerahan di kulit menghilang dan kulit tampak sandpaper yang kemudian menjadi deskwamasi setelah hari ketiga.

- Deskuamasi berbeda dengan campak karena lokasinya di lengan dan kaki. Deskuamasi kemudian akan mengelupas dalam minggu 1-6.

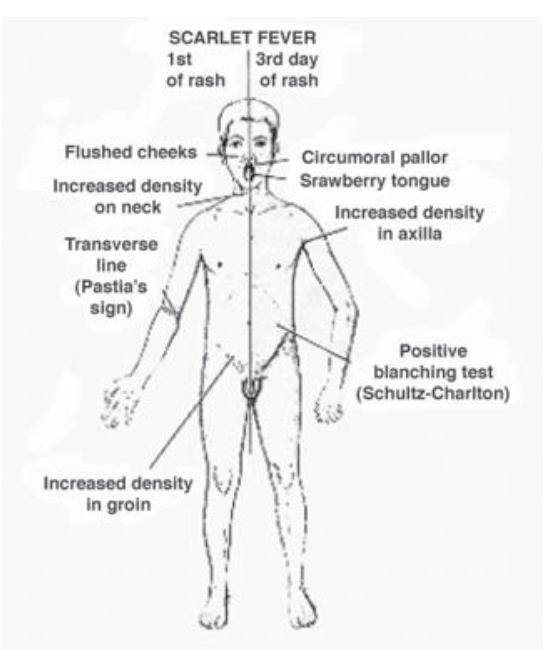


Diagnosis:

- Manifestasi klinis

- Kultur positif dari sekret nasofaring

- Serologis; peningkatan kadar anti streptolisin O (ASTO).

Komplikasi:

Abses tonsil, otitis media, bronko pneumonia, dan jarang menjadi mastoiditis, osteomielitis atau septikemia. Komplikasi lanjut adalah demam rematik dan glomerulonefritis akut.

Terapi:

- Penisilin per oral/IV, eritromisin atau sefalosporin yang diberikan sedini mungkin.

- Suportif.

\section{Stapylococcal Scalded Skin Syndrome (SSSS) $)^{3,4,6,11}$}

Etiologi : Staphyllo-coccus aureus (menghasil kan toksin eksfoliatif).

Fokus infeksi : Faringitis purulen, rinitis, konjung tivitis, luka atau infeksi umbilikal pada neonatus.

Manifestasi klinis:

Gejala prodromal berupa demam dan iritabel.

- Ruam berupa makula eritem tampak perttama kali di sekitar mulut dan hidung. Kulit tampak halus yang kemudian menyebar generalisata dan kemudian tampak seperti "sandpaper".

- Lesi terutama pada daerah fleksor, terutama lipat paha, aksila dan leher.

- Setelah 1-2 hari kulit menjadi berkerut dan dapat terjadi bula, mudah mengelupas (Nikolsky's sign), kulit nyeri bila disentuh. Selanjutnya 2-3 hari permukaan kulit menjadi kering dan berkrusta.

- Penyembuhan terjadi setelah 10-14 hari.

Diagnosis : Kultur dari kulit dan cairan bula.

Komplikasi : Sepsis dan endokarditis bakterialis.

Terapi :

- Suportif, mencegah sepsis, balans cairan dan elektrolit.

- Antibiotik resisten penisilinase.

- Kortikosteroid merupakan kontraindikasi mutlak karena dapat meningkatkan angka morbiditas dan mortalitas.
- Krim emolien dapat mengurangi rasa nyeri pada kulit yang terkelupas.

\section{Meningococcemia ${ }^{3,4-6}$}

Etiologi : Neisseria meningitidis (kuman Gram negatif)

Masa inkubasi : 2-10 hari

Manifestasi klinis:

- Infeksi nasofaring ringan

- Bakteriemia tanpa sepsis

- Meningokoksemia fulminan tanpa meningitis

- Meningitis dengan/tanpa mening okoksemia

- Meningokoksemia kronik

- Masa prodromal berupa nyeri tenggorokan, 2-8 jam kemudian diikuti dengan demam tinggi, nausea dan diare.

- Ruam berupa petekie pada kulit, jarang di membran mukosa. Berwarna merah, papula/ makula terdapat pada ekstremitas dan badan.

Diagnosis:

Pewarnaan Gram dan kultur dari darah, lesi kulit dan cairan serebrospinal.

Diagnosis banding:

Bakteriemia akut, endokarditis, demam rematik, purpura Henoch Schonlein, campak atipik dan rocky mountain spotted fever.

Terapi:

- Inisial terapi dengan antibiotik ampisilin dan kloramfenikol atau sefalosporin generasi ketiga. Setelah hasil kultur positif maka diberikan penisilin G 250.000 - $300.000 \mathrm{U} / \mathrm{kg} /$ hari dibagi dalam 6 kali pemberian selama 7-10 hari. Jika alergi terhadap penisilin, diberikan kloram fenikol 100 $\mathrm{mg} / \mathrm{kg} /$ hari (maksimal 4 gram/hari).

- Suportif, mencegah komplikasi.

\section{Eritema Infeksiosum (Fifth Disease). ${ }^{1,3,4,6}$}

\section{Etiologi : Parvovirus humanus B 19}

Cara penularan : Melalui alat rumah tangga dan droplet

Masa inkubasi : 5-16 hari (rata-rata 8 hari).

Manifestasi klinis:

- Tidak terdapat gejala prodromal yang khas, 
seringkali timbulnya ruam merupakan gejala awal dari penyakit.

- Karakteristik ruam terbagi dalam tiga stadium ;

(1) eksantema pada pipi berupa papuleritema tosa yang menjadi pucat pada penekanan, dikelilingi daerah pucat. Lesi kemudian meluas dan memberikan gambaran "slappedcheek". Kulit pada lesi terasa hangat dan bertahan sampai 4-5 hari.

(2) dimulai 1-4 hari timbulnya bercak pada wajah, timbul makula/papula/urtika eritematosa terutama pada ekstensor ekstremitas dan menyebar dan kebokong badan, lesi berkonfluensi dan terjadi penyembuhan yang ireguler sehingga memberikan gambaran retikuler/ anyaman.

(3) pada stadium ini eksantema berlangsung selama 1-6 minggu dan ditandai dengan eksantema yang hilang timbul.

Diagnosis:

Berdasarkan manifestasi klinis dan uji serologis.

Diagnosis banding:

Scarlet fever, rubela, roseola, infeksi enterovirus, SLE, ARJ, demam rematik dan erupsi obat.

Komplikasi:

Artritis akut pada dewasa, krisis aplastik pada penderita anemia hemolitik herediter, trombositopeni dan hidrops fetalis/IUFD bila terinfeksi selama hamil.

Terapi:

simptomatis

\section{Roseola Infantum (Exanthem Subitum) ${ }^{1-}$ $3,6,12-14$}

Etiologi : Human herpes virus tipe 6 (HHV 6)

Masa inkubasi : Sulit ditentukan karena kontak tidak diketahui.

Manifestasi klinis:

- Perjalanan penyakit dimulai dengan demam tinggi mendadak mencapai $40-40,6^{\circ} \mathrm{C}$, anak tampak iritabel, anoreksia, biasanya terdapat koriza, konjungtivitis dan batuk. Demam menetap 3-5 hari dan menurun secara mendadak ke suhu normal disertai timbulnya ruam.
- Ruam tampak pertama kali di punggung dan menyebar ke leher, ekstremitas atas muka, dan ektremitas bawah.

- Ruam berwarna merah muda, makulopapular, diskret, jarang koalesen sehingga mirip dengan lesi rubela.

- Lamanya timbul erupsi 1-2 hari, kadang dapat hilang dalam beberapa jam. Ruam hilang tidak meninggalkan bekas berupa pigmentasi atau deskuamasi.

Diagnosis:

Manifestasi klinis penurunan hitung leukosit.

Terapi:

Simptomatis.

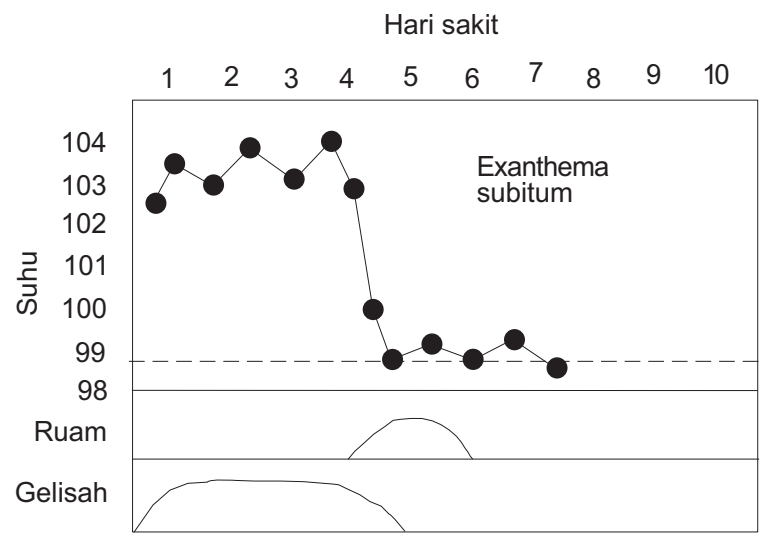

Miliaria $^{11}$

Etiologi : Sumbatan kelenjar keringat.

Manifestasi klinis:

- Dapat berupa miliaria kristalina dan miliaria rubra.Miliaria kristalina tanpa disertai dengan peradangan, sedangkan miliaria rubra disertai dengan peradangan dan lesi biasanya terlokalisir pada tempat oklusi atau daerah fleksor dimana kulit kemudian menjadi maserasi dan terlepas.

Terapi : Pendinginan dan pengaturan suhu lingkungan.

\section{Infeksi Varisela-Zoster ${ }^{3,6}$}

Etiologi : Varicella zoster.

Masa inkubasi : 14-27 hari 
Masa penularan : 2 hari sebelum dan 5 hari sesudah erupsi.

Manifestasi klinis:

- Masa prodromal 2-3 hari ditandai dengan demam, malaise, batuk, koriza dan nyeri tenggorokan serta gatal. Eksantema berawal dari lesi makulopapular yang kemudian menjadi vesikel berbentuk teardrop dan 2 hari kemudian menjadi pustul dan krusta. Penyembuhan total terjadi selama 16 hari.

Diagnosis:

- Manifestasi klinis

- Isolasi virus dari cairan vesikel

- Tes serologis.

Komplikasi:

Infeksi sekunder oleh bakteri, ensefalitis, sindrom Reye dan pneumonia.

Terapi:

- Bedak kocok kalamin + mentol.

- Antibiotik bila terdapat tanda infeksi.

- Asiklovir (atas indikasi)

\section{Hand-Foot-Mouth Disease (HFMD) $)^{1,3,6}$}

Etiologi : Coxsackievirus A 16.

Cara penularan : droplets

Masa inkubasi : 4-6 hari.

Manifestasi klinis :

- Masa prodromal ditandai dengan panas subfebris, anoreksia, malaise dan nyeri tenggorokan yang timbul 1-2 hari sebelum timbul enantem. Eksantem timbul lebih cepat dari pada enantem. Enantem adalah manifestasi yang paling sering pada HFMD.

Lesi dimulai dengan vesikel yang cepat menjadi ulkus dengan dasar eritem,ukuran 4-8 mm yang kemudian menjadi krusta, terdapat pada mukosa bukal dan lidah serta dapat menyebar sampai palatum uvula dan pilar anterior tonsil. Eksantema tampak sebagai vesiko pustul berwarna putih keabu-abu an, berukuran 3-7 mm terdapat pada lengan dan kaki termasuk telapak tangan dan telapak kaki, pada permukaan dorsal atau lateral, pada anak sering juga terdapat di bokong. Lesi dapat berulang beberapa minggu setelah infeksi, jarang menjadibula dan biasanya asimptomatik, dapat terjadi rasa gatal atau nyeri pada lesi. Lesi menghilang tanpa bekas.

Diagnosis::

Manifestasi klinis dan isolasi virus dengan preparat Tzank.

Diagnosis banding: Varisela, herpes.

Terapi: Simptomatis.

\section{Eczema Herpeticum ${ }^{3,6}$}

Etiologi : Virus herpes simpleks

Manifestasi klinis:

- Lesi berupa vesikel yang klinis bergerombol pada dasar eritematous, vesikel berkembang menjadi pustul yang kemudian pecah menjadi ulkus yang ditutupi oleh krusta berwarna kuning. Lesi dapat terasa nyeri atau gatal.

- Kekambuhan dapat terjadi karena trauma, demam atau sinar matahari, lokasi biasanya di mulut, genitalia atau tempat lain.

Terapi : Tidak ada yang spesifik.

\section{Impetigo $0^{3,6,11}$}

Etiologi : Streptococcus grup A, stafilokokus (jarang).

Manifestasi klinis:

- Tidak terdapat gejala prodromal.

- Lesi biasanya terbatas pada kulit.

- Dapat terjadi limfadenopati.

- Erupsi berupa vesikel yang pecah dengan cepat membentuk erosi purulen, ditutupi oleh krusta yang keras berwarna seperti madu. Lesi dapat tunggal atau banyak.

- Pada impetigo bulosa, bula yang flaksid dapat dipenuhi oleh pus.

Terapi : Antibiotik.

\section{Molluscum Contagiosum ${ }^{3,6}$}

Etiologi : Virus pox

Manifestasi klinis:

- Tidak terdapat gejala prodromal

- Erupsi berupa papul berbentuk kubah dengan 
diameter 2-10 $\mathrm{mm}$ disertai umbilikasi ditengahnya, warna merah seperti daging dan translusen. Lesi tersebar atau berkelompok.

- Penyembuhan secara spontan tanpa jaringan parut.

Terapi : Krioterapi, kuretase atau obat kera tolitik.

\section{Kesimpulan}

Dari seluruh gambaran penyakit eksantema yang hampir mirip satu dengan lainnya, kita dapat membedakan masing-masing penyakit dengan melihat dari gejala prodromal, karakteristik dan manifestasi klinis yang khas.

Untuk diagnosis banding dengan penyakit eksantema lainnya didasarkan pada riwayat penyakit dan imunisasi sebelumnya, bentuk gejala prodromal, gambaran erupsi kulit, adanya tanda patognomonik atau tanda lainnya, uji diagnostik laboratoris.

\section{Daftar Pustaka}

1. Hartley AH, Rasmussen JE. Infectious exanthems. Pediatric in review 1988; 9:321-9.

2. Krugman S, Katz SL, Gershon AA, Wilfert CM. Diagnosis of acute exanthematous diseases. Dalam: Krugman S, Katz SL, Gershon AA, Wilfert CM. Infectious diseases of children. Edisi ke-9. St Louis: Mosby Yearbook 1992. h. 631-9.

3. Frieden IJ, Penneys NS. Viral infection. Dalam: Schachner LA, Hansen RC, penyunting. Pediatric dermatology. Edisi ke-2. New york: Churchill Livingstone, 1995. h. 1257-94.
4. Gable EK, Liu G, Morrell DS. Pediatric exanthems. Prim Care 2000; 27:353-69.

5. Tumbelaka AR. Pendekatan diagnostik penyakit eksantema pada anak. Disampaikan pada Kongres Nasional Ilmu Kesehatan Anak XI, Jakarta, 4-7 juli, 1999.

6. Krafchik BR. Viral exanthems. Dalam: Harper J, Oranje A, Prose N, penyunting. Texbook of pediatric dermatology. London: Blackwell science 2000. h. 329-46.

7. Satgas Imunisasi IDAI. Jadwal imunisasi rekomendasi IDAI. Sari Pediatri; 2:43-7.

8. Cherry JD. Rubella. Dalam: Feigin RD, Cherry JD, penyunting. Texbook of pediatric infectious disease. Edisi ke-3. Philadelphia: WB Saunders, 1992. h. 1792-817.

9. Krugman S, Katz SL, Gershon AA, Wilfert CM. Rubella (German measles). Dalam: Krugman S, Katz SL, Gershon AA, Wilfert CM. Infectious diseases of children. Edisi ke-9. St Louis: Mosby year book 1992. h. 381-456.

10. American academy of pediatrics. Rubella. Red book: report of the committee on infectious diseases. Edisi ke25. American academy of pediatrics 2000. h. 495-500.

11. Habif. Exanthems and drug eruption. Clinical Dermatology. Edisi ke-3. St Louis: Mosby 1996. h. 409-44.

12. Krugman S, Katz SL, Gershon AA, Wilfert CM. Roseola infantum (exanthem subitum). Dalam: Krugman S, Katz SL, Gershon AA, Wilfert CM. Infectious diseases of children. Edisi ke-9. St Louis: Mosby yearbook 1992. h. 377-80.

13. Cherry JD. Roseola infantum (exanthem subitum). Dalam: Feigin RD, Cherry JD, penyunting. Texbook of pediatric infectious disease. Edisi ke-3. Philadelphia: WB Saunders, 1992. h. 1789-92.

14. Irving WL, Chang J, Raymond DR, Dunstan R, GrattanSmith P, Cunningham AL. Roseola infantum and other syndrome associated with acute HHV 6 infection. Arch Dis Child 1990; 65:297-300. 
Lampiran

Campak (measles/rubeola/morbili)
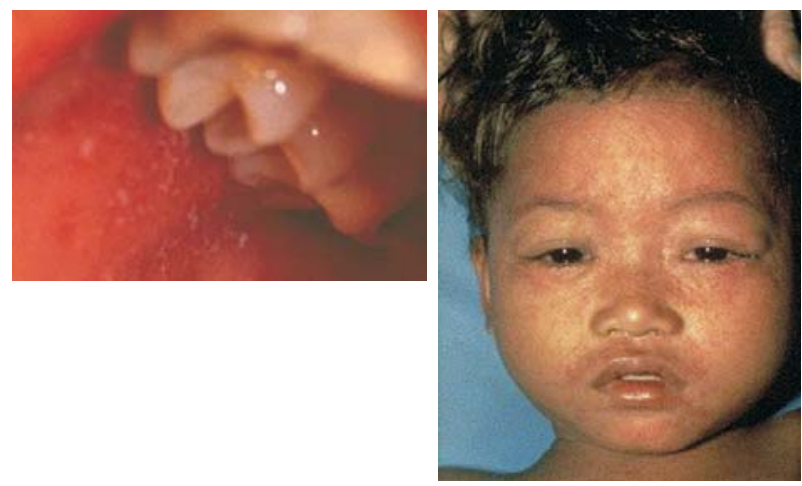

Rubela (German Measles).

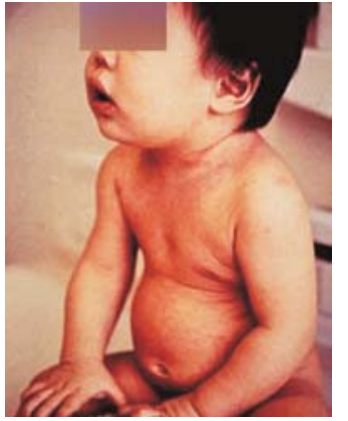

\section{Scarlet Fever (Scarlatina)}
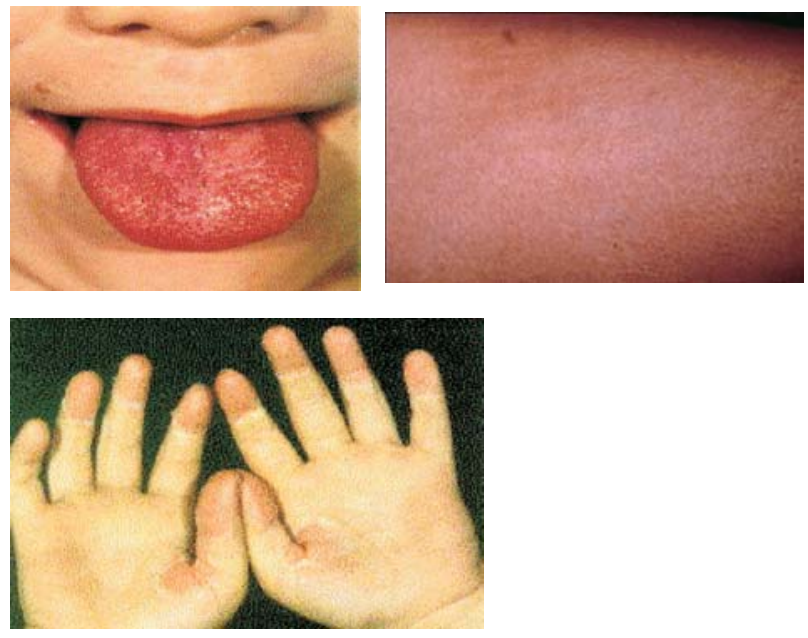

Stapylococcal Scalded Skin Syndrome (SSSS)

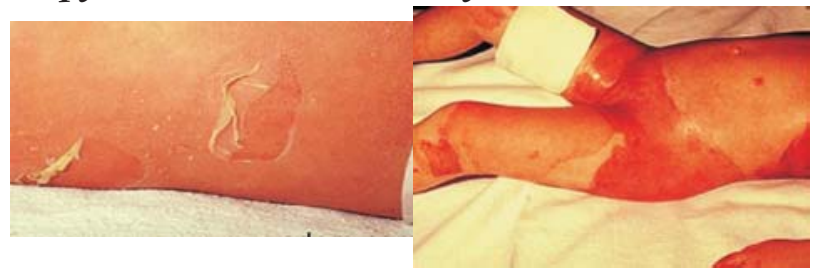

Sari Pediatri, Vol. 4, No. 3, Desember 2002

\section{Meningococcemia}

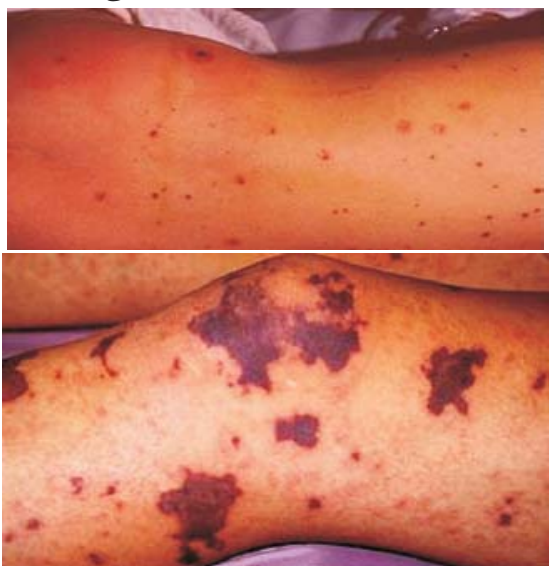

Eritema Infeksiosum (Fifth Disease).

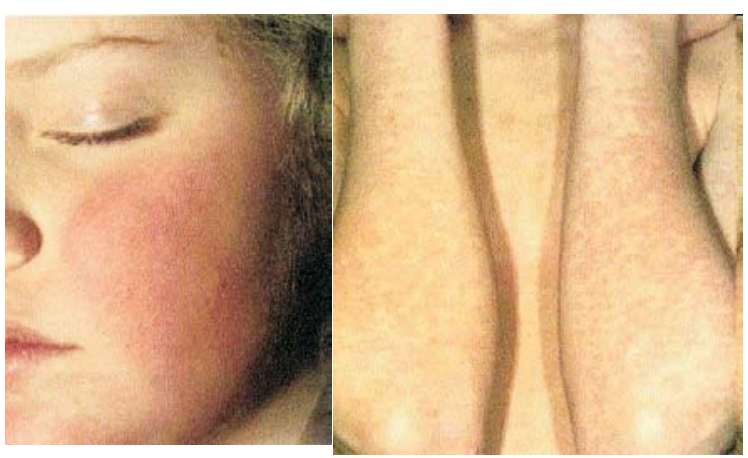

Roseola Infantum (Exanthem Subitum)

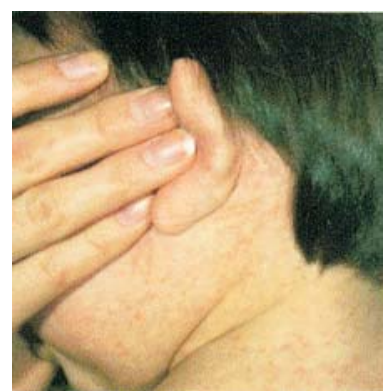

Miliaria

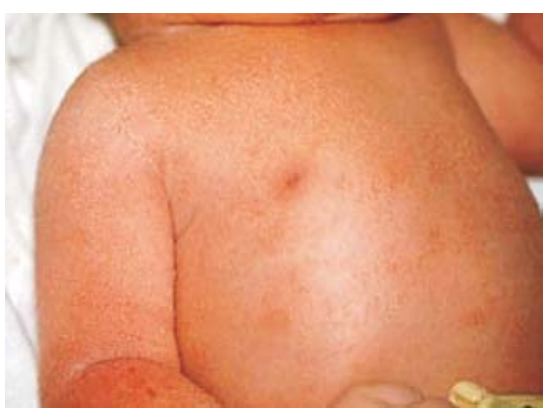


Infeksi Varisela-Zoster ${ }^{3,6}$
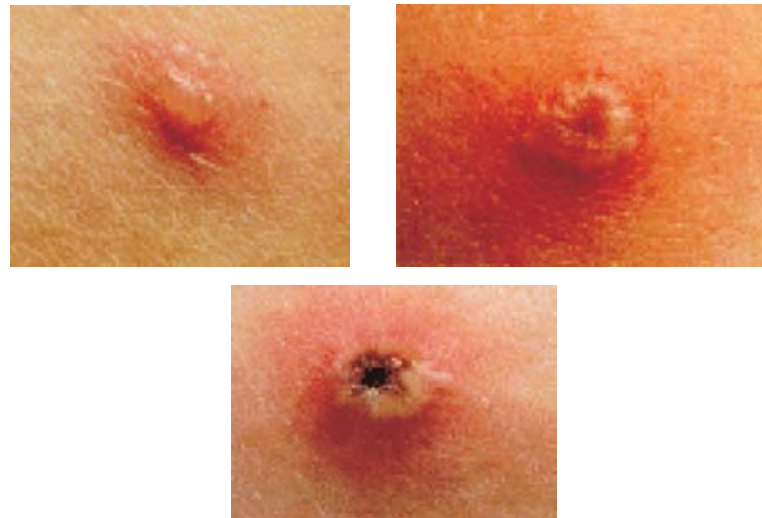

Hand-Foot-Mouth Disease (HFMD)1,3,6

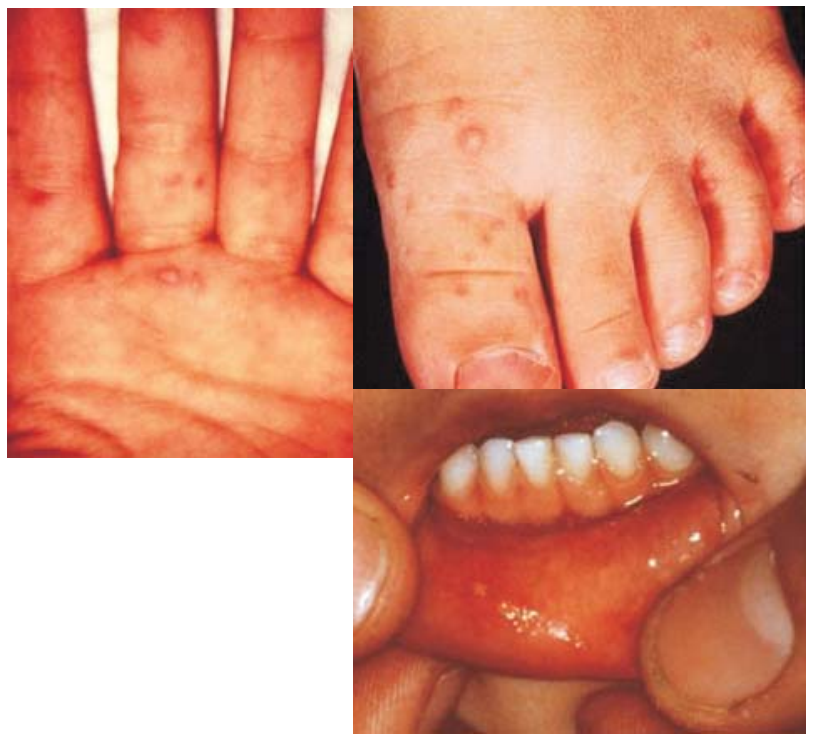

\section{Eczema Herpeticum ${ }^{3,6}$}
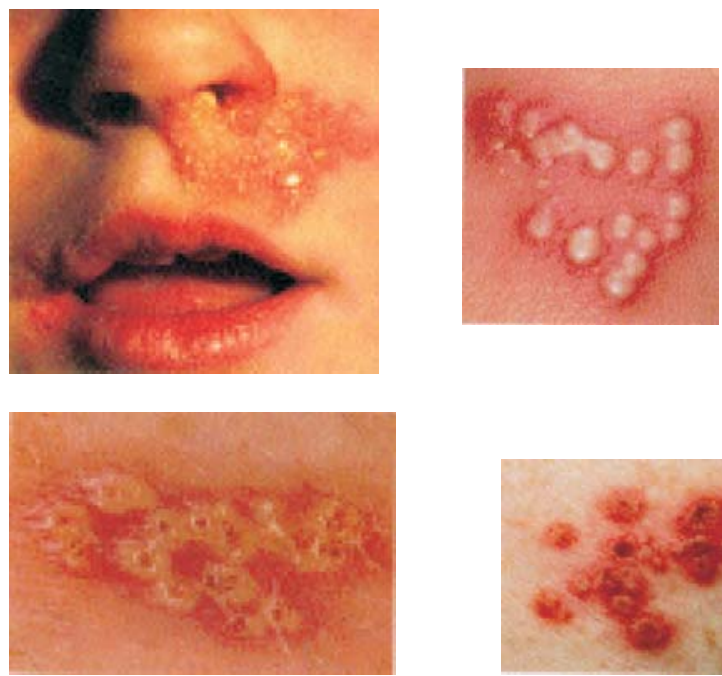

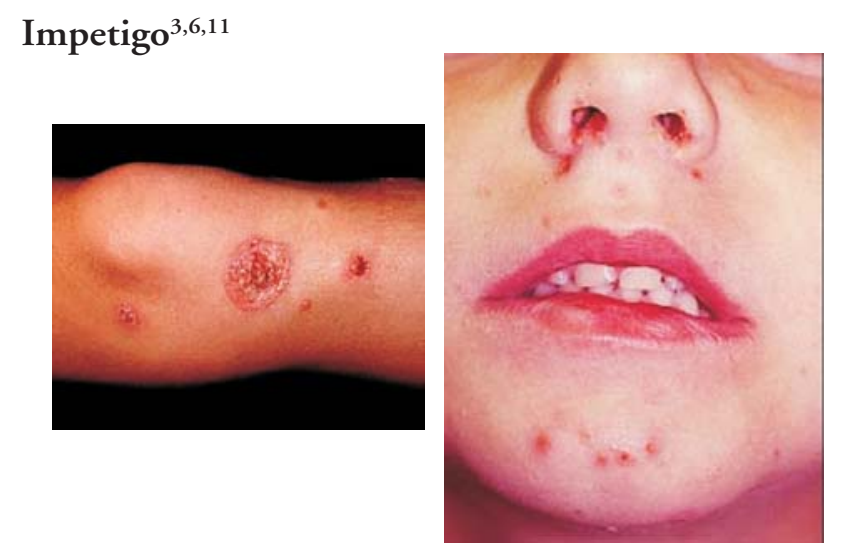

\section{Molluscum Contagiosum ${ }^{3,6}$}

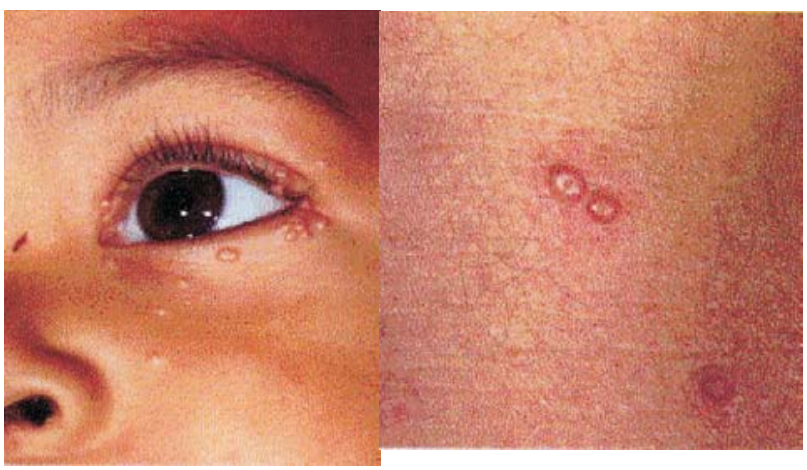

Tabel dan gambar :

1. Krugman S, Katz SL, Gershon AA, Wilfert CM. Infectious diseases of children. Edisi ke-9. St Louis: Mosby yearbook 1992 .

2. URL: htpp: //doctorkoop.net/conditions/ency/article. Diakses pada tanggal 20 Desember 2000. 